J. Membrane Biol. 25, 75-92 (1975)

(C) by Springer-Verlag New York Inc. 1975

\title{
Lithium Transport Across Isolated Frog Skin Epithelium
}

\author{
Peter S. Reinach, Oscar A. Candia, and George J. Siegel \\ Department of Ophthalmology, Mount Sinai School of Medicine of the City University \\ of New York, Fifth Avenue and 100th Street, New York, New York 10029 and Department \\ of Neurology, University of Michigan Medical Center, Ann Arbor, Michigan 48104
}

Received 24 March 1975; revised 27 June 1975

\begin{abstract}
Summary. Transepithelial $\mathrm{Li}^{+}$influx was studied in the isolated epithelium from abdominal skin of Rana catesbeiana. With $\mathrm{Na}^{+}$-Ringer's as inside medium and $\mathrm{Li}^{+}$-Ringer's as outside medium, the $\mathrm{Li}^{+}$influx across the epithelium was $15.6 \mu \mathrm{A} / \mathrm{cm}^{2}$. This influx was considerably reduced by removal of either $\mathrm{Na}^{+}$or $\mathrm{K}^{+}$from the inside bath or by the addition of ouabain or amiloride. Epithelial $\mathrm{K}^{+}$or $\mathrm{Na}^{+}$concentration was respectively lower in epithelia bathed in $\mathrm{K}^{+}$-free Ringer's or $\mathrm{Na}^{+}$-free Ringer's. In conditions of negligible $\mathrm{Na}^{+}$transport, a $20 \mathrm{mM} \mathrm{Li}^{+}$gradient (out $\rightarrow$ in) produced across the short-circuited epithelium $\mathrm{a} \mathrm{Li}^{+}$influx of $11.8 \mu \mathrm{A} / \mathrm{cm}^{2}$ and a mean short-circuit current of $10.2 \mu \mathrm{A} / \mathrm{cm}^{2}$. The same $\mathrm{Li}^{+}$gradient in the opposite direction produced a $\mathrm{Li}^{+}$outflux of only $1.9 \mu \mathrm{A} / \mathrm{cm}^{2}$. With equal $\mathrm{Li}^{+}$concentration $(10.3$ and $20.6 \mathrm{mM})$ on both sides of the epithelium, plus $\mathrm{Na}^{+}$ in the inside solution only, a stable $\mathrm{Li}^{+}$-dependent short-circuit current was observed. Net $\mathrm{Li}^{+}$movement (out $\rightarrow$ in) was also indirectly determined in the presence of an opposing $\mathrm{Li}^{+}$gradient. Although $\mathrm{Li}^{+}$does not substitute for $\mathrm{Na}^{+}$as an activator of the $\left(\mathrm{Na}^{+}+\mathrm{K}^{+}\right)$ATPase from frog skin epithelium, $\mathrm{Li}^{+}$influx appears to be related to $\mathrm{Na}^{+}-\mathrm{K}^{+}$pump activity. It is proposed that the permeability of the "outer barrier" to $\mathrm{Na}^{+}$and $\mathrm{Li}^{+}$is regulated by the electrical gradient produced by electrogenic $\mathrm{Na}^{+}-\mathrm{K}^{+}$pumps located in the membrane of the deeper epithelial cells.
\end{abstract}

It is generally accepted that active $\mathrm{Na}^{+}$transport across skin epithelium consists of at least two basic processes. First, $\mathrm{Na}^{+}$gains access to the epithelial cells across an "outer barrier" and second, it is transported from the cells to the inside medium across an "inner barrier". Initially, it was thought that the translocation across the "outer barrier" was a passive phenomenon and that active transport only occurred across the "inner barrier" and involved a 1:1 interchange of $\mathrm{Na}^{+}$for $\mathrm{K}^{+}$in a nonelectrogenic fashion [17]. The pump at the "inner barrier" was assumed to be closely related to the $\left(\mathrm{Na}^{+}+\mathrm{K}^{+}\right)$-ATPase system found in single cells. This is supported by the fact that ouabain causes inhibition of the transepithelial active $\mathrm{Na}^{+}$transport [16]. Furthermore, in toad bladder, there is a remarkable agreement between the inhibition curves 
for enzyme activity and transport [5]. The presence of $\left(\mathrm{Na}^{+}+\mathrm{K}^{+}\right)$ATPase in frog skin was first demonstrated by Bonting et al. [15].

More recently, a considerable amount of experimental evidence has shown that the "outer barrier" does not behave in a purely passive way $[2,4,12,13,19,22]$ and it has been proposed that an active mechanism is responsible for the entry of $\mathrm{Na}^{+}$into the epithelial cells $[18,26]$. One of the characteristics of the "outer barrier" is that $\mathrm{Na}^{+}$and $\mathrm{Li}^{+}$compete with one another for entry $[4,18]$ into the epithelial cells.

Candia and Chiarandini [9] have shown that, if $\mathrm{Na}^{+}$is present in the inside solution, a net $\mathrm{Li}^{+}$movement occurred across the frog skin that lasted for several hours. This $\mathrm{Li}^{+}$transport was inhibited by ouabain. They suggested that the $\left(\mathrm{Na}^{+}+\mathrm{K}^{+}\right)$-ATPase system may provide the energy for the $\mathrm{Li}^{+}$transport but need not be the carrier itself. This interpretation was in line with predictions in a model suggested by Candia [7] in which an electrical coupling exists between the energy source at the "inner barrier" and a rectifier at the "outside barrier".

The transepithelial $\mathrm{Li}^{+}$transport could also be explained (in a simpler manner) by assuming that $\mathrm{Li}^{+}$could replace $\mathrm{Na}^{+}$in the stimulation of the $\left(\mathrm{Na}^{+}+\mathrm{K}^{+}\right)$-ATPase system. However, this possibility is considered very unlikely since it has been recently found that $\mathrm{Li}^{+}$does not substitute for $\mathrm{Na}^{+}$in the activation of an ouabain-sensitive $\left(\mathrm{Na}^{+}+\mathrm{K}^{+}\right)$-ATPase from frog skin epithelium [24].

In this paper we provide evidence that in the isolated skin epithelium: a) $\mathrm{Na}^{+}$and $\mathrm{K}^{+}$requirements are common to $\mathrm{Na}^{+}$transport, $\mathrm{Li}^{+}$transport, and the enzyme system; b) Unidirectional $\mathrm{Li}^{+}$influx is significantly higher than $\mathrm{Li}^{+}$outflux. Their difference is equivalent to the shortcircuit current (SCC) in the absence of an appreciable net $\mathrm{Na}^{+}$transport; and c) $\mathrm{Li}^{+}$can be transported in the absence of and against an electrochemical gradient provided that $\mathrm{Na}^{+}$is present in the inside bathing medium. A model showing a possible coupling of the energy from the $\left(\mathrm{Na}^{+}+\mathrm{K}^{+}\right)$-ATPase system to the $\mathrm{Li}^{+}$transport is presented.

\section{Materials and Methods}

Most of the experiments were performed using the abdominal skin epithelium isolated from Rana catesbeiana. The epithelium was obtained from large animals weighing about $600 \mathrm{~g}$ kept in a container with tap water at room temperature $\left(21-23^{\circ} \mathrm{C}\right)$.

For the isolation of the epithelium, a method derived from that of Aceves and Erlij [1] and of Rajerison et al. [21] was used. A detailed description can be found in a previous publication [24]. Additional experiments were performed using the abdominal skin from Rana pipiens. 
Table 1. Composition of solution (values given in millimoles/liter)

\begin{tabular}{rlccc}
\hline No. & Solution & $\mathrm{Na}^{+}$ & $\mathrm{Li}^{+}$ & Choline $^{+}$ \\
\hline 1 & Na-Ringer's & 103 & 0 & 0 \\
2 & Li-Ringer's & $<0.1$ & 103 & 0 \\
3 & Choline-Ringer's & $<0.1$ & 0 & 103 \\
4 & Li 10-Choline-Ringer's & $<0.1$ & 10.3 & 92.7 \\
5 & Li 20-Choline-Ringer's & $<0.1$ & 20.6 & 82.4 \\
6 & Na 10-Choline-Ringer's & 10.3 & 0 & 92.7 \\
7 & Na 20-Choline-Ringer's & 20.6 & 0 & 82.4 \\
8 & Na 68-Choline-Ringer's & 68.7 & 0 & 34.3 \\
9 & Na 82-Choline-Ringer's & 82.4 & 0 & 20.6 \\
10 & Li 10-Na-Ringer's & 92.7 & 10.3 & 0 \\
11 & Li 20-Na-Ringer's & 82.4 & 20.6 & 0 \\
12 & Li 34-Na-Ringer's & 68.7 & 34.3 & 0 \\
\hline
\end{tabular}

Each solution contained, in addition to the above, the following in $\mathrm{mm}: \mathrm{K}^{+} 2.5 ; \mathrm{Ca}^{++}$ 1.8; $\mathrm{Cl}^{-} 105.5$; gluconate ${ }^{2-} 1.8$; and Tris- $\mathrm{HCl} 2.0$. The $\mathrm{pH}$ was 7.4.

\section{Electrical Measurements}

The epithelium was mounted in Lucite chambers that permitted electrical measurement across an area of $0.5 \mathrm{~cm}^{2}$. (In the experiments with Rana pipiens chambers with a crosssectional area of $2 \mathrm{~cm}^{2}$ were used.) The chamber and the mounting procedure is described in a previous publication [8]. The voltage and current bridges were polyethylene tubing filled with $3 \%$ agar dissolved in Ringer's. Voltage bridges were connected to the recording equipment (Electrometer Model 200B, Keithley Instruments, Cleveland, Ohio; and recorder Model EU 20, Heath Co., Benton Harbor, Michigan) by means of calomel cells. The SCC was measured with an automatic voltage-clamp system. The composition of the various Ringer's solutions used to bathe the epithelium is described in Table 1.

\section{Measurements of $\mathrm{Na}^{+}, \mathrm{Li}^{+}$, and $\mathrm{K}^{+}$Concentration}

The concentration of these cations was determined by flame photometry (Ependorf Model 700, Brinkmann Instruments, Westbury, N.Y.). When $\mathrm{Na}^{+}$was measured in $\mathrm{Li}^{+}-$ Ringer's and $\mathrm{Li}^{+}$and $\mathrm{Na}^{+}$-Ringer's, special care was taken to avoid error due to interference by the other ion.

\section{Determination of $\mathrm{K}^{+}$Content in the Skin Epithelium}

The skin epithelium isolated from one piece of skin was divided into 3 or 4 portions. One portion was bathed in a $\mathrm{K}^{+}$-free Ringer's for $130 \mathrm{~min}$. A second portion was bathed in regular Ringer's for $60 \mathrm{~min}$ and then transferred to a $\mathrm{K}^{+}$-free Ringer's for another $70 \mathrm{~min}$. The remaining one or two portions were used as controls and were bathed for the entire period of $130 \mathrm{~min}$ in Ringer's with $2.5 \mathrm{~mm} \mathrm{~K}{ }^{+}$concentration. The bathing solutions were periodically renewed and large enough so that $\mathrm{K}^{+}$lost from the epithelium did not increase the $\mathrm{K}^{+}$concentration. At the end of the incubation the extended layer of epithelium was photographed, gently bottled, weighed, and dissolved in nitric acid $(0.05 \mathrm{~N})$. This solution 
was slowly and completely evaporated at $60^{\circ} \mathrm{C}$. The solid residue was redissolved in distilled water and the $\mathrm{K}^{+}$concentration was determined. $\mathrm{K}^{+}$content is expressed per unit area and dry weight.

\section{Determination of $\mathrm{Na}^{+}$Content in the Skin Epithelium}

One obvious difficulty in the determination of the intracellular $\mathrm{Na}^{+}$concentration is to avoid including $\mathrm{Na}^{+}$that is in the extracellular space. We did not attempt to measure $\mathrm{Na}^{+}$content in control conditions (epithelium bathed in $\mathrm{Na}^{+}$-rich Ringer's) but only after the epithelium was incubated in choline-Ringer's ( $\mathrm{Na}$-free) for $85 \mathrm{~min}$. The remaining $\mathrm{Na}^{+}$ content was compared to values in the literature for control conditions. This permitted us to evaluate the effect produced by removal of $\mathrm{Na}^{+}$from the inside solution on the epithelial $\mathrm{Na}^{+}$concentration. The technical procedure for the $\mathrm{Na}^{+}$concentration measurement was the same as described for $\mathrm{K}^{+}$.

\section{Measurement of $\mathrm{Li}^{+}$-Originated Short-Circuit Current ${ }^{\wedge}$ Simultaneously with Unidirectional $\mathrm{Li}^{+}$andlor $\mathrm{Na}^{+}$Fluxes}

Several experimental conditions were designed in which $\mathrm{Na}^{+}$and $\mathrm{Li}^{+}$fluxes were measured across the isolated epithelium. Each side was bathed with solutions containing variable concentrations of $\mathrm{Na}^{+}, \mathrm{Li}^{+}$, and choline ${ }^{+}$whereas the concentration of other ions, $\mathrm{pH}$ and osmolarity was kept constant. For any given solution or mixture of solutions the addition of $\mathrm{Na}^{+}, \mathrm{Li}^{+}$, and choline ${ }^{+}$concentrations was equal to $103 \mathrm{~mm}$ (see Table 1). Unidirectional $\mathrm{Na}^{+}$fluxes were measured by adding ${ }^{22} \mathrm{Na}$ to one solution (about $2 \mu \mathrm{Ci} / \mathrm{ml}$ ) and taking periodic samples from the other. Specific activity in the labeled side was constant throughout the experiment, and the activity in the "cold" side was $1 \%$ or less of that in the labeled compartment. The radioactivity was measured with a well scintillation detector and a Packard spectrometer. When $\mathrm{Li}^{+}$fluxes were determined only one solution contained $\mathrm{Li}^{+}$while the opposite bathing solution was kept free of $\mathrm{Li}^{+}$or with a $\mathrm{Li}^{+}$concentration $1 \%$ or less of the Li-rich solution. $\mathrm{Li}^{+}$fluxes were calculated by periodically sampling the initially $\mathrm{Li}$-free solution and determining the $\mathrm{Li}^{+}$concentration in the samples.

\section{Results}

\section{$K^{+}$Content in the Isolated Epithelium: Effect of $K^{+}$-free Medium}

The outside barrier of the skin is almost impermeable to $\mathrm{K}^{+}$. It is expected that the epithelial cells will lose $\mathrm{K}^{+}$when bathed from the inside in a $\mathrm{K}^{+}$-free medium. From the data of Candia and Zadunaisky [11] (using the whole skin) it can be predicted that in $2 \mathrm{hr}$ the skin will lose about $0.64 \mu$ equiv of $\mathrm{K}^{+}$per $\mathrm{cm}^{2}$ of surface. To compare the decline

\footnotetext{
1 The reader should note that we use the term SCC to refer to the current measured when the potential difference (p.d.) across the epithelium is zero without regard to the chemical composition of the solutions bathing the epithelium. Thus, when the skin is bathed with different solutions, a fraction of the SCC may reflect passive diffusion rather than an active process.
} 
Table 2. Effect of potassium removal from the inside solution on short-circuit current and potassium content of the isolated frog skin epithelium

\begin{tabular}{|c|c|c|c|c|}
\hline \multirow[t]{2}{*}{ Outside solution } & \multirow[t]{2}{*}{ Inside solution } & \multirow{2}{*}{$\begin{array}{l}\mathrm{SCC} \\
\left(\mu \mathrm{A} / \mathrm{cm}^{2}\right)\end{array}$} & \multicolumn{2}{|l|}{$\mathrm{K}$ content } \\
\hline & & & 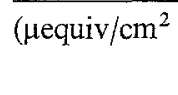 & $\begin{array}{l}\text { (uequiv/ } \\
\text { mg dry wt) }\end{array}$ \\
\hline $\mathrm{NaCl}$ Ringer's & $\begin{array}{l}\text { NaCl Ringer's } \\
\text { (control) }\end{array}$ & $\begin{array}{l}\mathrm{Na} \text { flux } \\
16.1 \pm 1.2(9)\end{array}$ & $0.60 \pm 0.08$ & $0.30 \pm 0.04$ \\
\hline $\mathrm{NaCl}$ Ringer's & $\begin{array}{c}\mathrm{NaCl} \text { Ringer's } \\
\left(\mathrm{K} \text {-free } 70^{\prime}\right)\end{array}$ & $10.2 \pm 1.3(9)$ & $0.50 \pm 0.05$ & $0.25 \pm 0.03$ \\
\hline $\mathrm{NaCl}$ Ringer's & $\begin{array}{l}\text { NaCl Ringer's } \\
\left(\mathrm{K} \text {-free } 130^{\prime}\right)\end{array}$ & $8.8 \pm 1.2(9)$ & $0.43 \pm 0.05$ & $0.22 \pm 0.03$ \\
\hline LiCl Ringer's & $\begin{array}{l}\mathrm{NaCl} \text { Ringer's } \\
\text { (control) }\end{array}$ & $\begin{array}{l}\text { Li flux } \\
15.6 \pm 1.3(7)\end{array}$ & & \\
\hline LiCl Ringer's & $\begin{array}{c}\text { NaCl Ringer's } \\
\left(\mathrm{K} \text {-free } 70^{\prime}\right)\end{array}$ & $10.2 \pm 1.1$ & & \\
\hline $\mathrm{LiCl}$ Ringer's & $\begin{array}{l}\mathrm{NaCl} \text { Ringer's } \\
\quad\left(\mathrm{K} \text {-free } 120^{\prime}\right)\end{array}$ & $4.8 \pm 0.6(7)$ & & \\
\hline
\end{tabular}

Each value is the mean $\pm \mathrm{SE}$.

of the SCC with the decline in intracellular $\mathrm{K}^{+}$content, three pieces from the same epithelium were incubated in a $\mathrm{K}^{+}$-rich medium for 130 min and in a $\mathrm{K}^{+}$-free medium for 70 and $130 \mathrm{~min}$, respectively. These results are shown in Table $2 . \mathrm{K}^{+}$content is significantly lower (as paired data) in epithelia incubated in a $\mathrm{K}^{+}$-free medium and there is a good correlation between the SCC and the epithelial $\mathrm{K}^{+}$content.

\section{$\mathrm{Na}^{+}$Concentration in the Isolated Epithelium: Effect of $\mathrm{Na}^{+}$-free Medium}

Ten pieces of epithelium from different frogs were exposed to $\mathrm{Na}^{+}$-free (choline) Ringer's for $85 \mathrm{~min}$. Periodic washouts were made to maintain the medium free of $\mathrm{Na}^{+}$. The $\mathrm{Na}^{+}$content in the epithelia at the end of the incubation was $0.00738 \pm 0.00126 \mu$ equiv $/ \mathrm{cm}^{2}$. Assuming the $\mathrm{Na}^{+}$ compartment in the epithelium to be $50-100 \mu$ thick, the concentration per volume would be $1.476-0.738 \mu$ equiv $/ \mathrm{cm}^{3}$, respectively. This concentration is a small fraction of the previously reported $\mathrm{Na}^{+}$concentration in normal skin epithelium (18-35 mM [26], $16 \mathrm{~mm}$ [18], $24.7 \mathrm{~mm}$ [1]). 


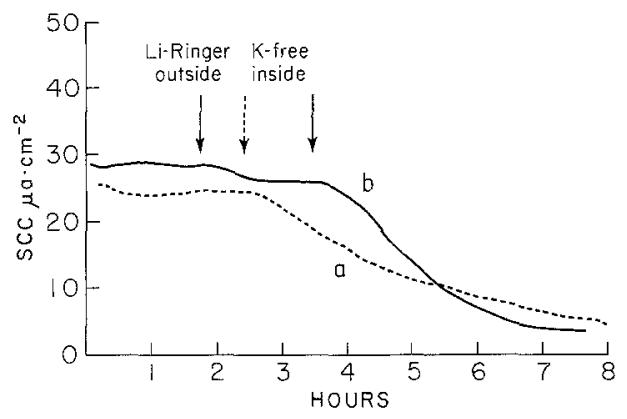

Fig. 1. Effects of $\mathrm{K}^{+}$-free Ringer's in the inside solution on the SCC of the isolated frog skin epithelium. a) $\mathrm{Na}^{+}$-Ringer's in the outside. Broken arrow indicates change of the inside medium from a $\mathrm{K}^{+}$-rich to a $\mathrm{K}^{+}$-free Ringer's. b) First arrow indicates change of the outside medium from a Na ${ }^{+}$-Ringer's to a $\mathrm{Li}^{+}$-Ringer's. Second arrow indicates change of the inside medium from a $\mathrm{K}^{+}$-rich to $\mathrm{K}^{+}$-free Ringer's

\section{Sodium and Lithium Short-Circuit Current : Effects of $K^{+}$-free Ringer's and Ouabain}

The SCC was measured in nine preparations bathed on both sides with $\mathrm{Na}^{+}$-Ringer's. After at least 45 min of stable SCC, the inside medium was replaced with a $\mathrm{K}^{+}$-free $\mathrm{Na}^{+}$-Ringer's and periodic washouts were made to insure a $\mathrm{K}^{+}$concentration of less than $0.10 \mathrm{~mm}$. This produced a slow decline of the SCC and p.d. as illustrated in Fig. 1a. After 130 min in $\mathrm{K}^{+}$-free Ringer's, the SCC was about $55 \%$ of the control and continued to decline to reach zero in about $9 \mathrm{hr}$. To study the effect of $\mathrm{K}^{+}$-free Ringer's on the $\mathrm{Li}^{+}$transport, another series of experiments was done in the following manner. The SCC was measured in epithelia bathed on both sides with $\mathrm{Na}^{+}$-Ringer's. After at least $30 \mathrm{~min}$ of stable SCC the outside medium was replaced with a $\mathrm{Li}^{+}$-Ringer's and periodic washouts were made with this solution to insure a $\mathrm{Na}^{+}$-free solution on the outside. The SCC with $\mathrm{Li}^{+}$-Ringer's in the outside was usually $10-20 \%$ smaller than the control SCC in $\mathrm{Na}^{+}$-Ringer's. This is different from the observation of Candia and Chiarandini in whole skins [9] where no difference between $\mathrm{Na}^{+}$and $\mathrm{Li}^{+} \mathrm{SCC}$ was found. After the $\mathrm{Li}^{+}-\mathrm{SCC}$ was stable for at least $45 \mathrm{~min}$ the inside medium was replaced with a $\mathrm{K}^{+}$-free $\mathrm{Na}^{+}$-Ringer's and the $\mathrm{K}^{+}$concentration in the inside was maintained below $0.10 \mathrm{~mm}$. The SCC declined to about $30 \%$ of the control $\mathrm{Li}^{+}-\mathrm{SCC}$ in 130 min (Fig. $1 b$ ).

Table 2 summarizes these results. The lack of $\mathrm{K}^{+}$in the inside medium definitely decreases the SCC when the skin is bathed on the outside with either $\mathrm{Na}^{+}$-Ringer's or $\mathrm{Li}^{+}$-Ringer's. 
Table 3. Effect of potassium removal and 50\% dilution of the Ringer's on electrical parameters of the isolated skin epithelium

\begin{tabular}{lcccccccccc}
\hline & $\begin{array}{l}\text { p.d.c } \\
(\mathrm{mv})\end{array}$ & p.d.k & p.d.d & \multicolumn{1}{l}{$\begin{array}{l}\mathrm{I}_{\mathrm{c}} \\
\left(\mu \mathrm{A} / \mathrm{cm}^{2}\right)\end{array}$} & $\mathrm{I}_{\mathrm{k}}$ & $\mathrm{I}_{\mathrm{d}}$ & $\begin{array}{l}\mathrm{R}_{\mathrm{c}} \\
\left(\mathrm{K} \Omega \mathrm{cm}^{2}\right)\end{array}$ & $\mathrm{R}_{\mathrm{k}}$ & $\mathrm{R}_{\mathrm{d}}$ \\
& & & & & & & & & \\
& 43 & 27 & 54 & 24.0 & 12.0 & 14.8 & 1.79 & 2.25 & 3.64 \\
& 52 & 32 & 61 & 24.0 & 12.0 & 15.5 & 2.08 & 2.66 & 3.93 \\
& 29 & 22 & 51 & 16.0 & 10.0 & 13.6 & 1.81 & 1.20 & 3.75 \\
& 27 & 25 & 40 & 18.0 & 10.5 & 15.0 & 1.50 & 2.38 & 2.67 \\
& 51 & 38 & & 18.8 & 11.2 & 16.2 & 2.71 & 3.39 & \\
Mean & 34 & 25 & 37 & 20.0 & 12.8 & 16.0 & 1.70 & 1.95 & 2.31 \\
SE & 39 & 28.2 & 48.6 & 20.1 & 11.4 & 15.2 & 1.96 & 2.47 & 3.26 \\
& 4.28 & 2.34 & 4.45 & 1.33 & 0.43 & 0.39 & 0.21 & 0.21 & 0.32 \\
\hline
\end{tabular}

p.d.: potential difference

I: $\mathrm{SCC}$

$\mathrm{R}$ : electrical resistance

c: control

k: K-free

d: K-free plus $50 \%$ dilution with distilled water

$I_{d}$ and p.d.d were stable after 10 min and remained constant for more than $1 \mathrm{hr}$. Readings were made within this period.

Ussing [25] had argued that the inhibition of the SCC caused by the lack of $\mathrm{K}^{+}$might be due to cell shrinkage as the cells lose $\mathrm{K}^{+}$to the bathing solution. He showed that after the $\mathrm{Na}^{+}$transport had been inhibited in a $\mathrm{K}^{+}$-free medium, dilution of the $\mathrm{K}^{+}$-free Ringer's to 0.5 strength with water restored the SCC as the skin swelled.

We made six such experiments with the isolated epithelium. The skin epithelium was bathed in regular $\mathrm{Na}^{+}$-Ringer's and a stable control SCC and p.d. were established. Then, the inside solution was replaced by a $\mathrm{K}^{+}$-free $\mathrm{Na}^{+}$-Ringer's (by means of three thorough washouts). About 80-90 min later a lower and stable SCC and p.d. were measured. Following this, both inside and outside Ringers's were diluted to 0.5 strength with distilled water. The experiment was continued for $60-90 \mathrm{~min}$. A partial recovery of the $\mathrm{SCC}$ was observed but it never reached the control value. The p.d., on the other hand, immediately rose in each case to values higher than the control. Table 3 shows results in detail. As previously seen in Table $2, \mathrm{~K}^{+}$-free Ringer's produces a $50 \%$ reduction of the SCC. However, dilution of the Ringer's restores the SCC to only $75 \%$ of the initial level.

The effect on the electrical resistance produced by these changes in solution is worth noting. The first change to a $\mathrm{K}^{+}$-free Ringer's increased 


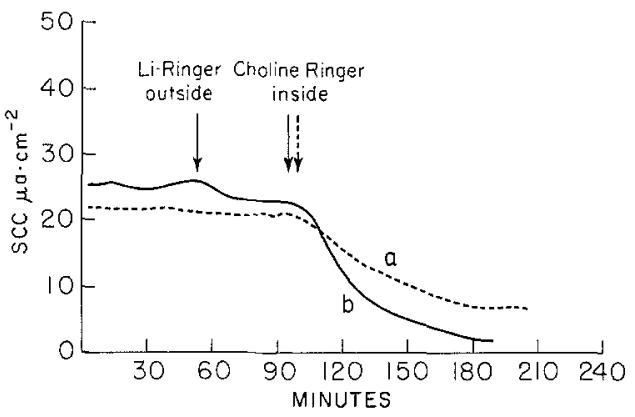

Fig. 2. Effects of $\mathrm{Na}^{+}$-free Ringer's in the inside solution on the SCC of the isolated skin epithelium. a) $\mathrm{Na}^{+}$-Ringer's in the outside. Broken arrow indicates change of the inside medium from a $\mathrm{Na}^{+}$-rich to a $\mathrm{Na}^{+}$-free Ringer's. $b$ ) First arrow indicates change of the outside medium from a $\mathrm{Na}^{+}$-Ringer's to a $\mathrm{Li}^{+}-$Ringer's. Second arrow indicates change of the inside medium from a $\mathrm{Na}^{+}$-rich to a $\mathrm{Na}^{+}$-free medium

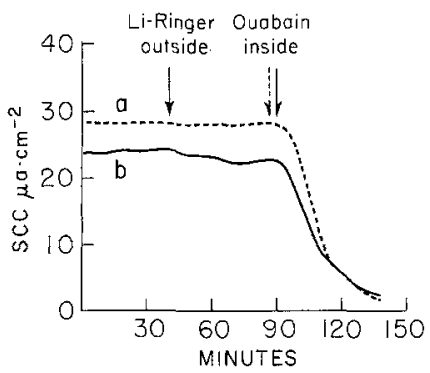

Fig. 3. Effects of ouabain $\left(10^{-4} \mathrm{M}\right)$ on the SCC of the isolated skin epithelium. $a$ ) $\mathrm{Na}^{+}$-Ringer's in both sides. Broken arrow indicated addition of ouabain. $b$ ) $\mathrm{Na}^{+}$-Ringer's in both sides. First arrow indicates change of the outside medium to $\mathrm{Li}^{+}$-Ringer's. Second arrow indicates addition of ouabain

the resistance as would be expected by an inhibition of the pump or cell shrinkage. However, the dilution of the Ringer's produced an additional and considerable increase in resistance in all cases. This is difficult to reconcile with Ussing's suggestion that dilution produces an exact reversal of the $\mathrm{K}^{+}$-free effect. Our results support the view that the removal of $\mathrm{K}^{+}$has an intrinsic effect on the pump.

Another series of experiments was done in which the $\mathrm{Na}^{+}$-Ringer's bathing the inside surface was replaced by a $\mathrm{Na}^{+}$-free choline ${ }^{+}$-Ringer's with the same $\mathrm{K}^{+}$concentration. The solution on the outside was either $\mathrm{Li}^{+}$-Ringer's or $\mathrm{Na}^{+}$-Ringer's. In both cases, the removal of $\mathrm{Na}^{+}$from the inside solution produced a sharp decline of the SCC (Fig. $2 a, b$ ). Rabito et al. also found that the SCC is a function of the $\mathrm{Na}^{+}$concentration in the inside bathing medium [20]. These results show that 
the presence of both $\mathrm{Na}^{+}$and $\mathrm{K}^{+}$in the inside solution is necessary to maintain a stable SCC regardless of whether $\mathrm{Na}^{+}$or $\mathrm{Li}^{+}$is producing the SCC. In a few experiments, ouabain $\left(10^{-4} \mathrm{M}\right)$ was added to the inside medium $\left(\mathrm{Na}^{+}\right.$-Ringer's) while the outside medium was either $\mathrm{Na}^{+}$or $\mathrm{Li}^{+}$Ringer's. In both cases, ouabain produced an immediate decline of the SCC (Fig. $3 a, b$ ).

\section{Unidirectional $\mathrm{Li}^{+}$Fluxes and Short-Circuit Current. $\mathrm{Li}^{+}$-Originated Short-Circuit Current in the Absence of $\mathrm{Li}^{+}$Gradient}

It has been previously shown [9] that a $\mathrm{Li}^{+}$influx essentially equal to the SCC can be maintained for several hours across the isolated frog skin provided that the inside bathing solution contained $\mathrm{Na}^{+}$. However, the $\mathrm{Li}^{+}$flux was down its chemical gradient and, although it was affected by ouabain and oxytocin (in the same fashion as the active $\mathrm{Na}^{+}$transport), there was not conclusive proof that metabolic energy was utilized for its transport. In this study, we measured both unidirectional $\mathrm{Li}^{+}$fluxes in equivalent conditions. For measuring the $\mathrm{Li}^{+}$influx, solution $\# 5$ (Table 1) was used on the outside and solution $\# 9$ on the inside of the skin. For measuring the $\mathrm{Li}^{+}$outflux, solution \#11 was on the inside and solution $\# 7$ on the outside. In this manner, the $\mathrm{Na}^{+}$concentration was, in both cases, $82.4 \mathrm{~mm}$ on the inside (required for preserving the transport properties of the epithelium) and near zero on the outside. At the same time, the $\mathrm{Li}^{+}$gradient was $20.6 / 0 \mathrm{~mm}$ in the direction of the $\mathrm{Li}^{+}$flux determination. Thus, the $\mathrm{Li}^{+}$gradient was symmetrical although the solutions were not identical. Results from 19 experiments are shown in Table 4.

The $\mathrm{Li}^{+}$influx, $0.44 \mu$ equiv/ $\mathrm{hr} \mathrm{cm}^{2}$, is 6 times larger than the outflux and their mean difference $0.35 \mu$ equiv $/ \mathrm{hr} \mathrm{cm}^{2}$, is equal to $93 \%$ of the SCC measured in the $\mathrm{Li}^{+}$influx experiments. The SCC in the $\mathrm{Li}^{+}$outflux experiments is Na-originated and only shows that the transport system was functioning during the $\mathrm{Li}^{+}$outflux experiments.

Table 4 also shows that amiloride reduces the transepithelial $\mathrm{Li}$ influx and outflux to about $0.03 \mu$ equiv $/ \mathrm{hr} \mathrm{cm}^{2}$. Unlike the $\mathrm{SCC}$, the $\mathrm{Li}^{+}$influx does not reach this low value immediately. This delay is probably due to the time required for the $\mathrm{Li}^{+}$present in the cells to leak out to the inside solution. Fig. 4 shows one experiment of this kind.

In some of these experiments, after the last amiloride period, ${ }^{22} \mathrm{Na}$ was added to the inside medium and the $\mathrm{Na}^{+}$outflux was determined. 
Table 4. Unidirectional Li fluxes and short-circuit current across isolated skin epithelium. Effect of amiloride $10^{-4} \mathrm{M}$

\begin{tabular}{lllll}
\hline $\begin{array}{l}\text { Successive } \\
\text { 30-min periods }\end{array}$ & $\begin{array}{l}\text { Li influx } \\
(\mu \text { equiv/hr cm }\end{array}$ & $\begin{array}{l}\mathrm{SCC}^{\mathrm{a}} \\
n=15)\end{array}$ & $\begin{array}{l}\text { Li outflux } \\
(\mu \text { equiv/hr cm }\end{array}$ & $\begin{array}{c}\mathrm{SCC}^{\mathrm{b}} \\
n=15)\end{array}$ \\
\hline Control-1 & $0.45 \pm 0.03$ & $0.41 \pm 0.03$ & $0.07 \pm 0.01$ & $0.82 \pm 0.13$ \\
Control-2 & $0.44 \pm 0.03$ & $0.38 \pm 0.03$ & $0.07 \pm 0.01$ & $0.84 \pm 0.14$ \\
Control-3 & $0.39 \pm 0.02$ & $0.35 \pm 0.03$ & $0.08 \pm 0.02$ & $0.81 \pm 0.15$ \\
Amiloride-4 & $0.24 \pm 0.03$ & $0.01 \pm 0.01$ & $0.02 \pm 0.01$ & $0.04 \pm 0.02$ \\
Amiloride-5 & $0.08 \pm 0.02$ & 0.00 & $0.01 \pm 0.01$ & 0.00 \\
Amiloride-6 & $0.05 \pm 0.01$ & 0.00 & $0.03 \pm 0.02$ & 0.00 \\
Amiloride-7 & $0.03 \pm 0.01$ & 0.00 & & \\
\hline
\end{tabular}

a The SCC indicated was obtained from the same experiments in which the $\mathrm{Li}^{+}$influx was measured. The SCC represents $\mathrm{Li}^{+}$movement. $\mathrm{Na}^{+}$concentration in the outside solution was less than $0.2 \mathrm{~mm}$.

${ }^{b}$ The SCC indicated was obtained from the epithelia in which the $\mathrm{Li}^{+}$outflux was measured. In these experiments, the $\mathrm{SCC}$ represented $\mathrm{Na}^{+}$transport.

Each value is the mean $\pm \mathrm{SE}$ of corresponding periods from number of experiments $(n)$. In 6 experiments, the $\mathrm{Na}^{+}$outflux was determined with ${ }^{22} \mathrm{Na}$ after the amiloride-7 period and a value of $0.053 \pm 0.009 \mu$ equiv $/ \mathrm{hr} \mathrm{cm}^{2}$ was found.

Amiloride was added at the end of control-3 period.

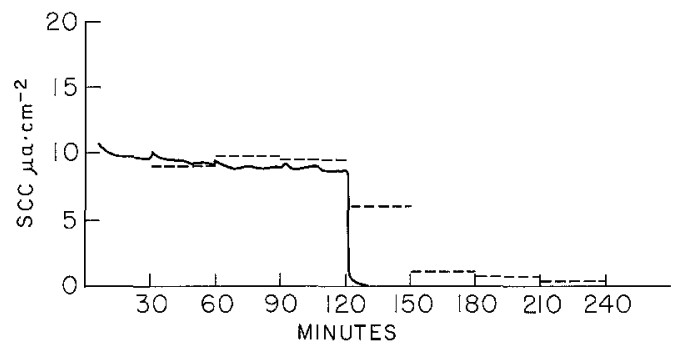

Fig. 4. Continuous recording of short-circuit current (solid line) and average $\mathrm{Li}^{+}$influx for seven 30-min periods (dashed line) across isolated frog skin epithelium. Outside bathing medium was solution $\#$ 5. Inside bathing medium was solution $\# 9$. Samples for $\mathrm{Li}^{+}$determination were taken every $30 \mathrm{~min}$. Amiloride $\left(10^{-4} \mathrm{M}\right)$ was added at the 120 -min mark

In all cases, the $\mathrm{Na}^{+}$outflux was between 0.02 and $0.08 \mu$ equiv $/ \mathrm{hr} \mathrm{cm}^{2}$ (less than $8 \%$ of $\mathrm{Na}$ influx) indicating the tightness of the epithelium and absence of appreciable edge damage. This type of experiment was also done using the intact abdominal skin of Rana pipiens and the results were the same.

In addition to these experiments, six more were done in which the epithelium was bathed on the outside with solution \#5 and on the inside with solution \#11, so that the $\mathrm{Li}^{+}$concentration was the same on both sides $(20.6 \mathrm{~mm})$. Na concentration in the outside was less than $0.2 \mathrm{~mm}$. 


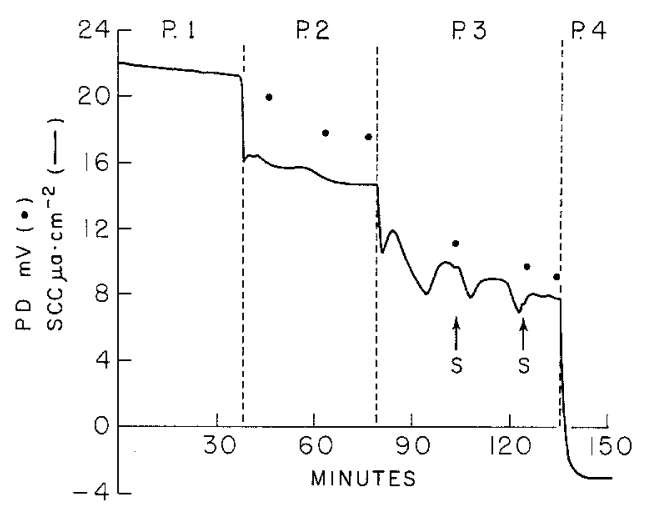

Fig. 5. SCC of the isolated frog skin epithelium. Phase 1: NaCl-Ringer's on both sides. Phase 2: Inside bathing medium was solution $\# 10$ and outside bathing medium was solution \#6. SCC current decreases due to the lowering of $\mathrm{Na}^{+}$concentration. Phase 3: Inside bathing medium is the same as in Phase 2 and outside bathing medium was solution \#4. A further decrease in SCC is observed. This smaller SCC is, however, stable for more than $2 \mathrm{hr}$ while the $\mathrm{Li}^{+}$concentration was $10.3 \mathrm{~mm}$ in both sides. $S$ indicates sampling. $\mathrm{Na}^{+}$concentration in the outside was $<0.22 \mathrm{mM}$. Phase 4: Inside solution is the same as in Phases 2 and 3 and the outside bathing medium was a choline Cl-Ringer's (solution \#3). SCC reverses due to the $\mathrm{Na}^{+}$gradient from the inside. $\mathrm{A} \mathrm{Na}^{+}$gradient was also present during Phases 2 and 3

The SCC in these experiments was $9.6 \pm 1.0 \mu \mathrm{A} / \mathrm{cm}^{2}$ which is similar to the net movement of $\mathrm{Li}^{+}$determined by unidirectional fluxes. After a period of 1 to $3 \mathrm{hr}$, the Ringer's on the inside was replaced by solution \#9 containing no $\mathrm{Li}^{+}$. After this change, the SCC did not change and the $\mathrm{Li}^{+}$influx measured was within $10 \%$ of the SCC. This result suggests that the $\mathrm{Li}^{+}$influx and the SCC originated by this flux is rather independent of a change in $\mathrm{Li}^{+}$concentration in the inside solution between 0 and $20 \mathrm{~mm}$.

The existence of a stable SCC in the absence of an electrochemical gradient for $\mathrm{Li}^{+}$(in conditions of negligible $\mathrm{Na}^{+}$transport) was also observed with $\mathrm{Li}^{+}$concentration of $10.3 \mathrm{~mm}$ on both sides of the epithelium.

One such experiment, out of a total of 12, is shown in Fig. 5. They were divided into four phases. In the first phase, the epithelium was bathed with normal Na-Ringer's on both sides $\left(\mathrm{Na}^{+}\right.$concentration $103 \mathrm{~mm}$ ). An average stable p.d. and SCC of $89 \mathrm{mV}$ and $22.7 \pm 1.9 \mu \mathrm{A} / \mathrm{cm}^{2}$ were obtained. In the second phase, the bathing solutions were \#10 on the inside and $\# 6$ on the outside. Stable p.d. and SCC during this phase were, respectively, $62 \mathrm{mV}$ and $13.3 \pm 1.2 \mu \mathrm{A} / \mathrm{cm}^{2}$. In the third phase, the outside solution was replaced by solution \#4. During this phase, the 
$\mathrm{Li}^{+}$concentration was the same $(10.3 \mathrm{~mm})$ on both sides of the epithelium. Nevertheless, a SCC was measured for $3 \mathrm{hr}$ or longer. This SCC was only 6.2. $\pm 0.4 \mu \mathrm{A} / \mathrm{cm}^{2}$ compared to the $\mathrm{Na}^{+}$current of $13.3 \mu \mathrm{A} / \mathrm{cm}^{2}$ in the second phase. Paired comparison of SCC between second and third phases showed a statistically significant decrease $(p<0.001)$ of $7.1 \mu \mathrm{A} / \mathrm{cm}^{2}$. Periodic washouts of the outside solution were made during this third phase and samples showed $\mathrm{Na}^{+}$concentrations of $0.22 \mu$ equiv $/ \mathrm{ml}$ or less. The SCC in the third phase could either be inhibited by ouabain or stimulated by oxytocin. Other experiments were continued into a fourth phase. During this phase, the outside solution was choline-Ringer's $\left(\mathrm{Na}^{+}\right.$and $\mathrm{Li}^{+}$-free). Samples of the outside solution showed a $\mathrm{Na}^{+}$concentration of $0.21 \mu$ equiv $/ \mathrm{ml}$ or less. The p.d. and SCC immediately reversed due to the opposing $\mathrm{Na}^{+}$gradient. This suggests that the $\mathrm{SCC}$ in the third phase was a minimum estimate of $\mathrm{Li}^{+}$transport. In most experiments, periodic oscillations of the type described by Finkelstein [14] (with a period of about $8 \mathrm{~min}$ were observed during the third phase). These experiments show that $\mathrm{Li}^{+}$(at $10.3 \mathrm{~mm}$ concentration) is transported in the absence of $\mathrm{a} \mathrm{Li}^{+}$gradient and further suggests a direct or indirect coupling to an active mechanism.

\section{Lithium Flux Against a Chemical Gradient and Unidirectional $\mathrm{Na}^{+}$Influx}

One possible type of coupling for $\mathrm{Li}^{+}$movement is by a mechanism of co- or counter-transport to the movement of $\mathrm{Na}^{+}$. With a very low $\mathrm{Na}^{+}$concentration in the outside solution the $\mathrm{Na}^{+}$outflux probably exceeds the influx and the net $\mathrm{Na}^{+}$flux is opposite to the net $\mathrm{Li}^{+}$flux. Thus, the possibility exists that the $\mathrm{Li}^{+}$influx is driven by the $\mathrm{Na}^{+}$gradient in a counter-transport fashion. With a larger $\mathrm{Na}^{+}$concentration in the outside solution (about $2 \mathrm{~mm}$ ) the net $\mathrm{Na}^{+}$movement, although small, is in the direction of the net $\mathrm{Li}^{+}$movement. In this case, the $\mathrm{Li}^{+}$influx may be coupled to the $\mathrm{Na}^{+}$movement in a co-transport fashion. It is clear that there must be a $\mathrm{Na}^{+}$concentration in the outside solution at which the net transepithelial $\mathrm{Na}^{+}$movement changes direction. This concentration is undoubtedly between 0.1 and $2 \mathrm{mM}$. Thus, it was of interest to study the $\mathrm{Li}^{+}$influx while the outside $\mathrm{Na}^{+}$concentration was maintained within this range. This was done in the following manner. The epithelium was mounted in the chamber and the outside face was bathed with solution \#5, while the inside face was bathed with solution \#8. The p.d. was short-circuited. After stabilization of the SCC a known 


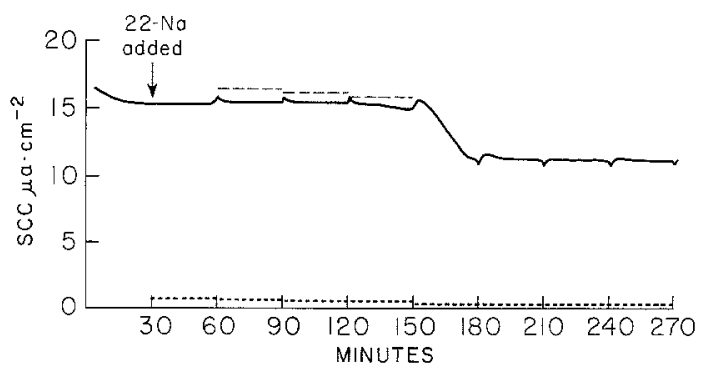

Fig. 6. Continuous recording of short-circuit current (solid line), average $\mathrm{Li}^{+}$influx (dashed line) and average $\mathrm{Na}^{+}$influx (dotted line) across isolated frog skin epithelium. Samples for measurement of ${ }^{22} \mathrm{Na}$ activity and determination of $\mathrm{Li}^{+}$concentration (when possible) were taken every $30 \mathrm{~min}$. The outside bathing medium was, for the entire length of the experiment, solution $\# 5$ with a small amount of $\mathrm{Na}(0.1 \mathrm{~mm})$ and ${ }^{22} \mathrm{Na}$ label added. The inside bathing medium was: before the 150 -min mark solution $\# 9$, and after the 120 -min mark solution \#12

amount of $\mathrm{NaCl}$ was added to the outside medium so that the $\mathrm{Na}^{+}$ concentration could be adjusted to values varying (in different experiments) between 0.1 and $1.4 \mathrm{~mm}$. This produced no change or a small (up to $5 \%$ ) increase in the SCC. Following this, ${ }^{22} \mathrm{Na}$ was added to the outside solution. Afterward, samples were taken from the inside solution every $30 \mathrm{~min}$ for $2 \mathrm{hr}$ so that the $\mathrm{Li}^{+}$and $\mathrm{Na}^{+}$fluxes were determined simultaneously with the SCC (Fig. 6). The $\mathrm{Li}^{+}$influx closely matches the SCC while the $\mathrm{Na}^{+}$influx is only a small fraction of it. In a second phase of these experiments the Ringer's in the inside face was quickly replaced by solution $\# 12$. After this change, the inside $\mathrm{Li}^{+}$concentration was $34.3 \mathrm{mM} . \mathrm{Li}^{+}$influx could no longer be measured but SCC and $\mathrm{Na}^{+}$ influx were measured for four more periods. The SCC decreased to a new stable value and the $\mathrm{Na}^{+}$influx remained very low. These results are shown in Table 5.

The most feasible interpretation for the discrepancy between the SCC and $\mathrm{Na}^{+}$influx is to assume that the $\mathrm{Li}^{+}$influx continued at a level similar to the SCC and could account for it. This $\mathrm{Li}^{+}$transport was occurring against a chemical gradient (20.6/34.3). The $\mathrm{Li}^{+}$and $\mathrm{Na}^{+}$outflux were not measured in these experiments but they have been measured in other experiments and represented no more than $0.09 \mu$ equiv $/ \mathrm{hr} \mathrm{cm}^{2}$ for a wide range of conditions including the one described here. $\mathrm{The}^{2}{ }^{+}$ transport we observe has no relation to variations in outside $\mathrm{Na}^{+}$concentration from near zero to $1.42 \mathrm{mM}$. Also, the $\mathrm{Na}^{+}$movement in either direction is very small compared to the net $\mathrm{Li}^{+}$transport. Thus, a simple coupling of $\mathrm{Li}^{+}$transport to $\mathrm{Na}^{+}$movement (either co- or countertransport) cannot explain these results. 
Table 5. Li Influx, short-circuit current, and $\mathrm{Na}$ influx across isolated skin epithelium down and against a Li concentration gradient

\begin{tabular}{|c|c|c|c|c|c|c|c|}
\hline \multirow{2}{*}{$\begin{array}{l}\text { Experi- } \\
\text { ment }\end{array}$} & \multicolumn{2}{|c|}{$\mathrm{Na}(\mathrm{mm})$} & \multicolumn{2}{|c|}{$\mathrm{Li}(\mathrm{mM})$} & Li influx $x^{a}$ & $\mathrm{Na}$ influx ${ }^{\mathrm{a}}$ & \multirow[t]{2}{*}{$\mathrm{SCC}^{\mathrm{a}}$} \\
\hline & out & in & in & out & \multicolumn{2}{|c|}{ ( $\mu$ equiv/ $/ \mathrm{hr} \mathrm{cm}^{2}$ ) } & \\
\hline $1 \mathrm{~L}$ & 1.30 & 82.4 & 0 & 20.6 & 0.68 & 0.08 & 0.69 \\
\hline $1 \mathrm{~L}$ & 1.30 & 68.7 & 34.3 & 20.6 & - & 0.06 & 0.45 \\
\hline $2 \mathrm{~L}$ & 0.10 & 82.4 & 0 & 20.6 & 0.73 & 0.005 & 0.65 \\
\hline $2 \mathrm{~L}$ & 0.10 & 68.7 & 34.3 & 20.6 & - & 0.003 & 0.36 \\
\hline $3 \mathrm{~L}$ & 0.40 & 82.4 & 0 & 20.6 & 0.59 & 0.021 & 0.56 \\
\hline $3 \mathrm{~L}$ & 0.40 & 68.7 & 34.3 & 20.6 & - & 0.015 & 0.32 \\
\hline $4 \mathrm{~L}$ & 1.42 & 82.4 & 0 & 20.6 & 0.90 & 0.075 & 0.62 \\
\hline $4 \mathrm{~L}$ & 1.42 & 68.7 & 34.3 & 20.6 & - & 0.045 & 0.46 \\
\hline $5 \mathrm{~L}$ & 0.44 & 82.4 & 0 & 20.6 & 0.63 & 0.025 & 0.65 \\
\hline $5 \mathrm{~L}$ & & 68.7 & 34.3 & 20.6 & - & 0.014 & 0.41 \\
\hline
\end{tabular}

a Each number in these columns is an average from 3 to 4 periods. Additional description in the text.

\section{Discussion}

It is generally accepted that the energetic requirements of $\mathrm{Na}^{+}$transport across frog skin epithelium are provided by the $\left(\mathrm{Na}^{+}+\mathrm{K}^{+}\right)$-ATPase system. The main evidence for this is that ouabain, a potent inhibitor of the $\mathrm{Na}^{+}$pump and of $\left(\mathrm{Na}^{+}+\mathrm{K}^{+}\right)$-ATPase in other tissues, also inhibits transepithelial $\mathrm{Na}^{+}$transport across frog skin. Since $\mathrm{Li}^{+}$does not activate the frog skin epithelium $\left(\mathrm{Na}^{+}+\mathrm{K}^{+}\right)$-ATPase [24], it is clear that the observed transepithelial $\mathrm{Li}^{+}$transport cannot be explained by a direct $\mathrm{Li}^{+}$activation (replacing $\left.\mathrm{Na}^{+}\right)$, of the $\left(\mathrm{Na}^{+}+\mathrm{K}^{+}\right)$-ATPase. Nevertheless, the $\left(\mathrm{Na}^{+}+\mathrm{K}^{+}\right)$-ATPase system seems to be related to the $\mathrm{Li}^{+}$transport. The main support for this argument is that $\mathrm{Li}^{+}$transport is inhibited by ouabain and by $\mathrm{Na}^{+}$- or $\mathrm{K}^{+}$-free Ringer's. Candia and Chiarandini [9] have measured the $\mathrm{Li}^{+}$flux before and after ouabain inhibition and found a good correlation with the SCC. The $\mathrm{Li}^{+}$-originated SCC can also be stimulated with oxytocin and depressed by amiloride. These results suggest that the transepithelial $\mathrm{Li}^{+}$flux from the outside to the inside follows the same pathway as the active $\mathrm{Na}^{+}$transport flux.

The results in Tables 4 and 5 are conclusive in showing that an equivalent $\mathrm{Li}^{+}$gradient $(20 \mathrm{~mm})$ produces an influx that is six times larger than the outflux. The difference between these two flux values corresponds to the measured SCC. Therefore, either without or against a $\mathrm{Li}^{+}$gradient, 
the SCC can only be explained by a net inward $\mathrm{Li}^{+}$transport. The $\mathrm{Li}$ originated SCC does not change when the $\mathrm{Li}^{+}$concentration in the inside medium is raised from 0 to $20.6 \mathrm{~mm}$, but it did decline when the concentration was raised to $34.3 \mathrm{~mm}$. However, the $\mathrm{Na}^{+}$concentration was reduced during the latter change and this may be the cause of the decline.

Leblanc [18] reported that in epithelia bathed with $\mathrm{Na}^{+}$-Ringer's on the inside and $\mathrm{Na}^{+}$-free, $\mathrm{Li}^{+}$-Ringer's on the outside a SCC proportional to the $\mathrm{Li}^{+}$concentration was measured. He also found that the so-called intracellular $\mathrm{Li}^{+}$accumulation has a saturation level of about $30 \mathrm{~mm}$. This saturation is attained with an outside $\mathrm{Li}^{+}$concentration of $10 \mathrm{~mm}$ and remains unaltered upon increasing the outside $\mathrm{Li}^{+}$concentration. This saturation curve is similar to that reported for $\mathrm{Na}^{+}$[12]. The intracellular $\mathrm{Na}^{+}$concentration in skin epithelium is also in the range of $18-35 \mathrm{~mm}$ $[1,18,26]$. Leblanc [18] concluded that the permeability of the outer barrier might be controlled by cell metabolism. Zerahn [26] found that dinitrophenol reduced the epithelial $\mathrm{Na}^{+}$content while ouabain increased it. Both Zerahn and Leblanc proposed that an active transport step may exist at the level of the outer barrier. Moreno et al. [19] have found that ouabain produces a considerable inhibition (comparable to that produced by amiloride) of the $\mathrm{Na}^{+}$uptake at the outer barrier. Their conclusion was that either the $\mathrm{Na}^{+}$pool does not exist, ouabain acts directly on an active step at the outer barrier, or the $\mathrm{Na}^{+}$permeability of the outer barrier is controlled by the epithelial $\mathrm{Na}^{+}$concentration. We have found that the $\mathrm{Na}^{+}$content of epithelium incubated in Na-free medium is very low $\left(0.007 \mu\right.$ equiv $\left./ \mathrm{cm}^{2}\right)$. On the other hand, ouabain increased the intracellular $\mathrm{Na}^{+}$concentration in both the isolated skin epithelium [1, 23] and isolated cells from the skin epithelium [27]. Although these two experimental conditions have opposite effects on the epithelial $\mathrm{Na}^{+}$content, an inhibition of the $\mathrm{Na}^{+}$and $\mathrm{Li}^{+}$transport is observed in both cases. Thus, the intracellular $\mathrm{Na}^{+}$concentration cannot be the regulator of the permeability of the outer barrier.

The transepithelial $\mathrm{Li}^{+}$transport is dependent on the presence of $\mathrm{Na}^{+}$ and derives energy from the $\left(\mathrm{Na}^{+}+\mathrm{K}^{+}\right)$-ATPase system without activating the enzyme. However, a simple counter-transport between the $\mathrm{Na}^{+}$ outflux (due to the $\mathrm{Na}^{+}$gradient) and the uphill $\mathrm{Li}^{+}$movement is unlikely. This is supported by the fact that ouabain considerably reduces $\mathrm{Li}^{+}$influx without having a significant effect on the $\mathrm{Na}^{+}$outflux. Thus, the type of coupling remains obscure.

As a working hypothesis a qualitative interpretation of these results follows. A schematic representation of frog skin epithelium is shown in 


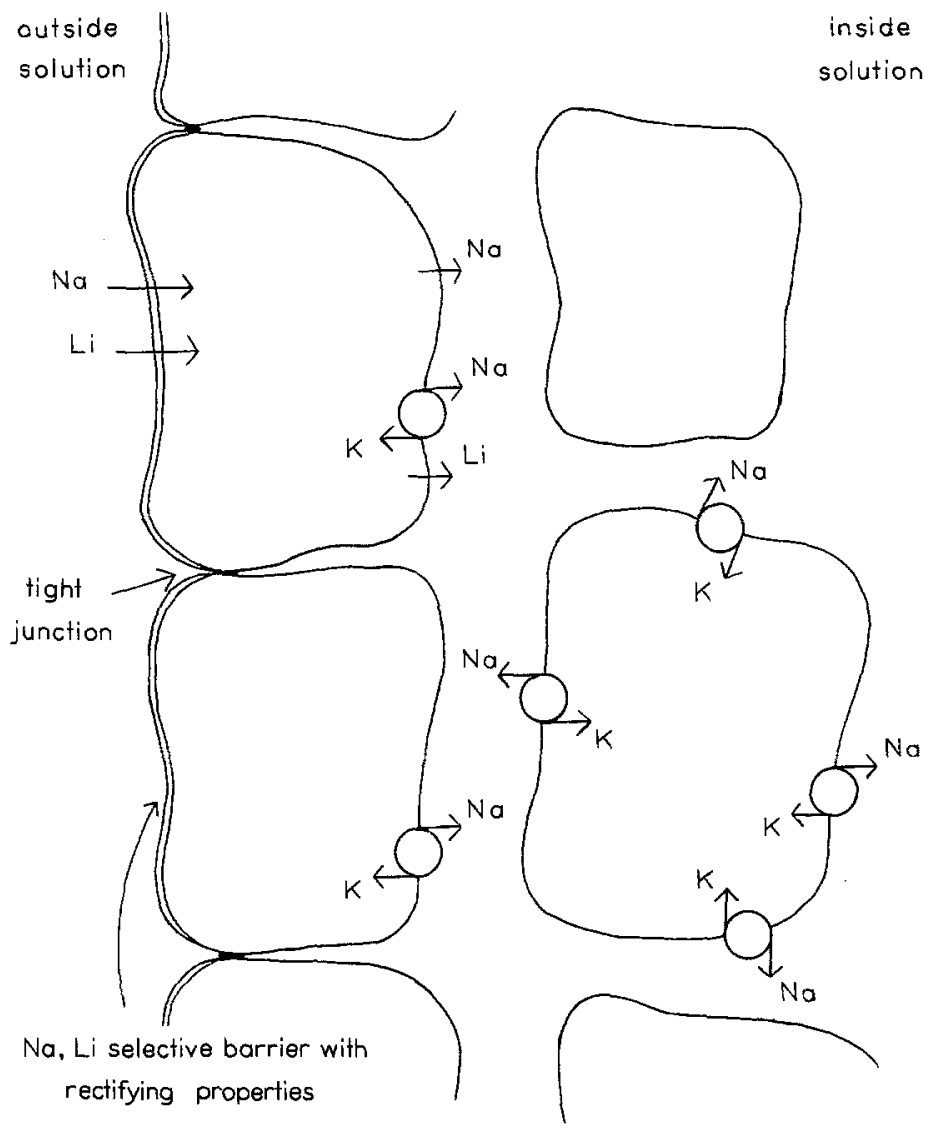

Fig. 7. Schematic diagram of the frog skin epithelium to describe hypothetical mechanisms of $\mathrm{Na}^{+}$and $\mathrm{Li}^{+}$transport - discussed in the text. Arrow $(\rightarrow)$ indicates diffusion due to electrochemical gradient. Circle with two arrows represents a $\mathrm{Na}: \mathrm{K}$ pump

Fig. 7. The outermost active cell layer acts as a selective permeability barrier to $\mathrm{Na}^{+}$and $\mathrm{Li}^{+}$[4] and also possesses diode-type rectifying properties for these cations [7,9]. This barrier seems to be the rate-limiting step of the transepithelial $\mathrm{Na}^{+}$flux $[3,10,13]$, and is affected by amiloride and oxytocin. When properly electrically biased as a result of metabolic activity of $\mathrm{Na}^{+}: \mathrm{K}^{+}$pumps present elsewhere in the epithelium, this barrier will allow $\mathrm{Na}^{+}$and $\mathrm{Li}^{+}$from the outside solution to passively enter the outermost cell layer driven by the electrical gradient although against a concentration gradient. The leak of $\mathrm{Na}^{+}$or $\mathrm{Li}^{+}$from this layer back to the outside solution is negligible [10]. The paths of $\mathrm{Na}^{+}$and $\mathrm{Li}^{+}$ movement from this point to the inside solution may be different. $\mathrm{Na}^{+}$ 
may either diffuse or be pumped into the intercellular spaces by the $\mathrm{Na}^{+}: \mathrm{K}^{+}$pump. Since the $\mathrm{Na}^{+}$flux is larger than the $\mathrm{K}^{+}$uptake across the inner barrier [11], it is conceivable that a fraction of the $\mathrm{Na}$ flux proceeds by diffusion. If $\mathrm{Na}^{+}: \mathrm{K}^{+}$pumps are symmetrically distributed in the membrane of other cell layers, they cannot participate in the transepithelial transport unless they also possess asymmetrical characteristics as the first active layer. Ouabain will affect the $\mathrm{Na}^{+}: \mathrm{K}^{+}$pumps and the electrical bias across the "rectifying barrier" and as a consequence of this, $\mathrm{Na}^{+}$entry from outside will decrease. However, intracellular $\mathrm{Na}^{+}$ concentration will increase due to leakage from the inside solution. Operationally, the $\mathrm{Na}^{+}$transport pool will be the $\mathrm{Na}^{+}$content of the cell layer or layers with asymmetrical characteristics. The intracellular $\mathrm{Na}^{+}$ is then expected to be larger than the $\mathrm{Na}^{+}$transport pool. $\mathrm{Na}^{+}$pumped into the intracellular spaces by the first active layer could reach the inside solution either by diffusing into additional deeper cells and ultimately be pumped by these cells, or simply by diffusing along the intercellular spaces. $\mathrm{Li}^{+}$, on the other hand, cannot be pumped by the $\mathrm{Na}^{+}: \mathrm{K}^{+}$pumps, so it must proceed by diffusion. This requires that the $\mathrm{Li}^{+}$concentration in the active layer be larger than in the intercellular spaces. This will set limitations on the conditions under which a net $\mathrm{Li}^{+}$transport can occur. Low $\mathrm{Na}^{+}$concentration in the intracellular compartment will stop the $\mathrm{Na}^{+}: \mathrm{K}^{+}$pump and the entrance of $\mathrm{Li}^{+}$across the outer barrier. Ouabain will produce a similar effect. With $10-20 \mathrm{mM} \mathrm{Li}^{+}$concentration in both the inside and outside solutions (and presumably in the intercellular spaces) the concentration of $\mathrm{Li}^{+}$in the active cell layer (30 mM or more) is larger than in the intercellular spaces and a net transport of $\mathrm{Li}^{+}$can be observed in the absence of an electrochemical gradient. Even though $\mathrm{Li}^{+}$may not be translocated by a "pump" its movement depends upon metabolic energy, related to the $\mathrm{Na}^{+}: \mathrm{K}^{+}$pump. The energy required for the net $\mathrm{Li}^{+}$movement is derived from the electrical gradient created across the outer barrier by the $\mathrm{Na}: \mathrm{K}$ pump.

\section{References}

1. Aceves, J., Erlij, D. 1971. Sodium transport across the isolated epithelium of the frog skin. J. Physiol. 212:195

2. Biber, T.U.L., Chez, R.A., Curran, P.E. 1966. Na transport across frog skin at low external Na concentrations. J. Gen. Physiol. 49:1161

3. Biber, T.U.L., Cruz, L.J. 1973. Effect of antidiuretic hormone on sodium uptake across outer surface of frog skin. Amer. J. Physiol. 225:912

4. Biber, T.U.L., Curran, P.F. 1970. Direct measurement of uptake of sodium at the outer surface of the frog skin. J. Gen. Physiol. 56:83 
5. Bonting, S.L., Canady, M.R. 1964. Na-K activated adenosine triphosphatase and sodium transport in toad bladder. Amer. J. Physiol. 207:1005

6. Bonting, S.L., Caravaggio, L.L., Hawkins, N.M. 1962. Studies on sodium-potassiumactivated adenosinetriphosphatase. IV. Correlation with cation transport sensitive to cardiac glycosides. Arch. Biochem. Biophys. 98:413

7. Candia, O.A. 1970. The hyperpolarizing region of the current-voltage curve in frog skin. Biophys. J. 10:323

8. Candia, O.A. 1972. Ouabain and sodium effects on chloride fluxes across the isolated bullfrog cornea. Amer. J. Physiol. 223:1053

9. Candia, O.A., Chiarandini, D.J. 1973. Transport of lithium and rectification by frog skin. Biochim. Biophys. Acta 307:578

10. Candia, O.A., Reinach, P. 1975. The $\mathrm{Na}$ pool and Na fluxes across inner and outer barriers of frog skin epithelium. Biophys. J. 15:228a ( $\not 2$ Abstract)

11. Candia, O.A., Zadunaisky, J.A. 1972. Potassium flux and sodium transport in the isolated frog skin. Biochim. Biophys. Acta 225:517

12. Cereijido, M., Herrera, F.C., Flanigan, W.J., Curran, P.F. 1964. The influence of Na concentration on Na transport across frog skin. J. Gen. Physiol. 47:879

13. Erlij, D., Smith, M.W. 1973. Sodium uptake by frog skin and its modification by inhibitors of transepithelial sodium transport. J. Physiol. $228: 221$

14. Finkelstein, A. 1961. Lithium-induced oscillations of potential and resistance in isolated frog skin. J. Gen. Physiol. 44:1165

15. Kawada, J., Taylor, R.E., Jr., Barker, S.B. 1969. Measurement of Na-K-ATPase in the separated epidermis of Rana catesbeiana frogs and tadpoles. Comp. Biochem. Physiol. 30:965

16. Koefoed-Johnsen, V. 1957. The effect of $g$-Strophanthin (ouabain) on the active transport of sodium through the isolated frog skin. Acta Physiol. Scand. 42 (Suppl. 145):87

17. Koefoed-Johnsen, V., Ussing, H.H. 1958. The nature of the frog skin potential. Acta Physiol. Scand. 42:298

18. Leblanc, G. 1972. The mechanism of lithium accumulation in the isolated frog skin epithelium. Pflugers Arch. 337:1

19. Moreno, J.H., Reisin, I.L., Rodriquez Boulan, E., Rotunno, C.A., Cereijido, M. 1973. Barriers to sodium movement across frog skin. J. Membrane Biol. 11:99

20. Rabito, C.A., Rodriquez Boulan, E., Cereijido, M. 1973. Effect of the composition of the inner bathing solution on transport properties of the frog skin. Biochim. Biophys. Acta $311: 630$

21. Rajerison, R.M., Montegut, M., Jard, S., Morel, F. 1972. The isolated frog skin epithelium: Permeability characteristics and responsiveness to oxytocin, cyclic AMP and theophylline. Pflugers Arch. 332:302

22. Rotunno, C.A., Vilallonga, F.A., Fernandez, M., Cereijido, J. 1970. The penetration of sodium into the epithelium of the frog skin. J. Gen. Physiol. 55:716

23. Rotunno, C.A., Zylber, E.A., Cereijido, M. 1973. Ion and water balance in the epithelium of the abdominal skin of the frog Leptodactylus ocellatus. J. Membrane Biol. 13:217

24. Siegel, G.J., Tormay, A., Candia, O.A. 1975. Microsomal sodium-potassium-activated adenosinetriphosphatase from frog skin epithelium: Cation activation and some effects of inhibitors. Biochim. Biophys. Acta 389:557

25. Ussing, H. 1965. Transport of electrolytes and water across epithelia. Harvey Lect. 59:1

26. Zerahn, K. 1969. Nature and localization of the sodium pool during active transport in the isolated frog skin. Acta Physiol. Scand. 77:272

27. Zylber, E.A., Rotunno, C.A., Cereijido, M. 1973. Ion and water balance in isolated epithelial cells of the abdominal skin of the frog Leptodactylus ocellatus. J. Membrane Biol. 13:199 